\title{
プラズマパルス堆積法による酸素含有硬質炭素薄膜の形成
}

\author{
山田秀雄・辻 理* \\ 栃木県県南工業指導所, 327-0847 栃木県佐野市天神町 950 \\ *(株)サムコインターナショナル研究所， 612-8443 京都市伏見区竹田䕗屋町 36
}

\section{Oxygen Containing Hard Amorphous Carbon Thin Films by Plasma Pulsed Deposition Method}

\author{
Hideo YAMADA and Osamu TSUJI* \\ Kennan Industrial Research Institvite of Tochigi Prefecture, 950, Tenjin-cho, Sano-shi, Tochigi 327-0847 \\ *Samco International Inc., 36, Takeda Waraya-cho, Fushimi-ku, Kyoto-shi 612-8443
}

\begin{abstract}
Hard amorphous carbon thin films containing small amounts of oxygen were deposited by the radio frequency $(13.56 \mathrm{MHz})$ self-bias method, using isopropanol as a starting material. The effect of the deposition temperature and the behavior of oxygen atoms during the film depositions were investigated in detail with controlling the deposition temperature by the plasma pulsed deposition technique. As a result, the deposition rates decreased by about $50 \%$ as compared with the diamond-like carbon film depositions from isobutane, because deoxygenation reactions from the films actively progressed. The effect of the deposition temperature was almost similar to that found in the diamond-like carbon film depositions but, an increase in the film density and a decrease of the film surface micro-roughness were recognized. The deposited films were considered to consist of a three-dimensional network structure of carbon chains, within which carbonyl structures and graphite-like carbon clusters were intermixed. Furthermore, as the film formation ability of the applied deposition method in this study was exceedingly high, $\mathrm{C}=\mathrm{C}=\mathrm{O}$ structures in the deposited films were observed by FT-IR spectroscopy, which was considered to be the precursors for the deoxygenation reactions from the films.

[Received September 24, 1998; Accepted December 3, 1998]
\end{abstract}

Key-words : Hard amorphous carbon thin film, Diamond-like carbon film, Doses of oxygen, Self-bias method, Isopropanol, Plasma pulsed deposition method, Precursor for the deoxygenation reaction

\section{1. 緒 言}

アルコールなどの含酸素化合物を出発物質として用いた薄膜 形成に関する研究事例はダイヤモンド薄膜の形成 ${ }^{1)}$ 12) に関す る報告等が知られているが，これらはダイヤモンドの合成を目 的としたものであり, プラズマ中で発生する $\mathrm{OH}$ ラジカル等 を有効に活用して成膜を行おうとするものである。一方，アモ ルファス状の炭素薄膜を形成しようとする場合，出発物質中に 酸素を含んでいると酸素の脱離反応が活発に進行するため薄膜 を形成しにくいことが知られており，わずかに Komathらに よるメタノールを出発物質として用いたダイヤモンド状炭素薄

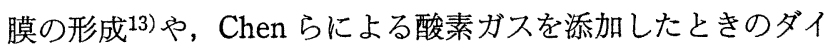
ヤモンド状炭素薄膜の形成 ${ }^{14)}$ 等に関する報告がなされている に過ぎず，酸素を薄膜中に含有した硬質炭素薄膜の形成に関す る報告はほとんど見られない，著者らはすでにいくつかのアル コール類を出発物質として，これに，基板側に高周波を印加し 発生する自己バイアス電压を積極的に活用する成膜方法（自己 バイアス法）を適用することでアモルファス状の硬質薄膜が容 易に形成されることを報告している15).

一方, 自己バイアス法は装置的な制約から, 成膜温度を制御 することが難しく, 成膜温度が薄膜特性に及ぼす影響を詳細に 検討することは困難であった．著者らはこれらを解決するため に, 蛍光式光ファイバー温度計を用い, しかもパルス的な成膜 手法を適用することで, 自己バイアス法における成膜温度の影 響について，すでにダイヤモンド状炭素薄膜の形成等に関して さまざなな視点から検討を加えてきた ${ }^{16) ~ 20) . ~}$

今回, 酸素含有硬質炭素膜の作製において, 同様な成膜手法 を適応することで, 成膜温度の影響について検討を行うととも に, 従来から実施してきたイソブタンを出発物質とするダイヤ モンド状炭素薄膜の形成との比較を行うこと等により, 出発物
質中に含まれる酸素の挙動について詳細に検討を加えた。

\section{2. 実 験}

\section{1 反応装置, 及び反応パラメーター}

本研究に用いたプラズマ反応装置 (サムコインターナショナ ル研究所製, BP-1）は平行平板型の内部電極型で, 下部電極 側に高周波を印加することにより発生する自己バイアス電圧を 積極的に活用し, 成膜を行う装置である. 今回は, 高周波電源 をコントローラーを用いて制御することによりパルス的 $(5 \mathrm{~s}$ の成膜と 3 min の冷却期間の繰り返し）に成膜を行うことで, イオンインパクトによる成膜温度の上昇を制御しつつ, 薄膜を 形成した. 高周波の出力は $100 \mathrm{~W}$ 及び $200 \mathrm{~W}$, 反応压力は 20 $\mathrm{Pa}$ 一定とした. 出発物質はイソプロパノールで, 市販のもの （純度 $99.5 \%$ 以上）を液体窒素で涷結させ，真空引きによる脱 気操作を行った後, ニードルバルブで所定の压力に調整し，プ ラズマ反応器へ導入した.

\section{2 成膜温度}

既報16) 々同様に, 蛍光式光ファイバー温度計 (安立計器製, AMOTH FX-8500）を用いて成膜中の温度を直接測定した。

成膜中は, 下部電極上には自己バイアス電圧によりイオン シースが発生するが，温度センサーの挿入によるシースの乱れ やプラズマ状態の乱れは, 目視上全く観察されなかった。

又, 基板側に $15^{\circ} \mathrm{C}$ の水を循環させ, 高周波の出力を $100 \mathrm{~W}$ 及び $200 \mathrm{~W}$ としたときの，12パルス分の温度変化は図 1 のと おりで， $5 \mathrm{~s}$ の成膜による急激な温度上昇と, $3 \mathrm{~min}$ の冷却に よる温度下降の繰り返しになる．このとき, 各パルスにおける 中間値をとり，その 12 パルス分の平均を成膜温度とした。こ の他の各成膜温度の設定は，下部電極側に設置されているヒー ターの温度制御により行った。 


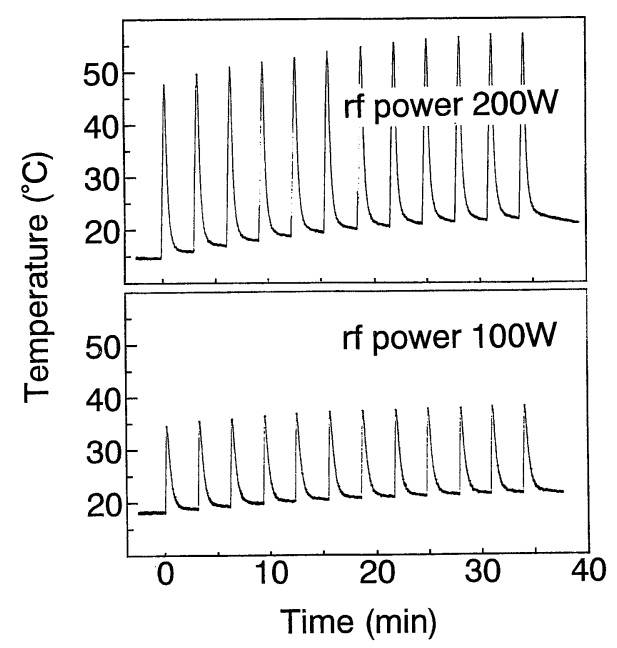

Fig. 1. Deposition temperature trace recorded using a fluorescent/optical thermosensor probe.

\section{3 成膜速度及び薄膜密度}

従来の方法と同様な手法 ${ }^{16)} に よ り$ 膜厚及び質量を測定し， 成膜速度を求めた。 また，この測定值から薄膜の密度を算出し た.

\section{4 内部応力}

触針法（東京精密製，575A3DF）により成膜後のそりを測 定し, 内部応力を求めた. このとき, 成膜前の $\mathrm{Si}(100)$ 基板自 体のそりをあらかじめ測定しておくことで，補正を行った．用 いた基板のサイズは径約 $76 \mathrm{~mm}$, 厚さは約 $0.5 \mathrm{~mm}$ で, 薄膜 は約 $0.2 \mu \mathrm{m}$ の厚さに成膜した．また，測定温度を変化させた ときの内部応力変化を FLX-2320 (KLA-Tencor 製) により 測定した.

\section{5 薄膜硬度}

シリコンウエハーの基板上に約 $2 \mu \mathrm{m}$ の厚さに成膜した薄膜 についてヌープ硬度を測定した，用いた硬度計は MVK-G2 （明石製作所製）で，荷重は $49 \times 10^{-3} \mathrm{~N}, 5$ 回測定した平均值 をヌープ硬度とした.

\section{6 マイクロラフネス}

試料はシリコンウエハー基板上に，高周波出力，及び成膜温 度を変えて作製した，成膜時間はいずれの場合も $30 \mathrm{~s}$ (6 パル ス分）一定とした。

表面観察及び粗さの測定は原子間力顕微鏡（Seiko Instruments, SPA-300）を用いて行った.このとき，エタノールに よる超音波洗浄を $5 \mathrm{~min}$ 行った試料表面について $2 \times 2 \mu \mathrm{m}$ の 範囲を観察し，粒子状の異物がない所を 5 か所選び，測定長 約 $1 \mu \mathrm{m}$ についての $R_{\mathrm{a}}$ (平均粗さ) を計測することで薄膜のマ イクロラフネスとした.

\section{7 赤外スペクトル}

薄膜硬度を測定した各試料について, 透過法により赤外スペ クトルを測定した，用いた装置は，日本電子製の JIR-5500で ある。

\section{8 ラマンスペクトル}

薄膜硬度を測定した試料について, 顕微ラマン法によりラマ ンスペクトルを測定した．用いた装置は JRS-SYSTEM1000 (日本電子製) であり, 光源としては $\mathrm{Ar}^{+}$レーザー $(514.5 \mathrm{~nm})$ を用い, 測定時間 $20 \mathrm{~s}$, 測定領域約 $20 \mu \mathrm{m}$ 径, レーザー出力 約 $0.6 \mathrm{~mW}$ の条件で測定した.

\section{9 電子プローブ微小部分析}

薄膜硬度を測定した各試料について，電子プローブ微小部分 析（EPMA）により組成分析を行った．装置は JCXA-733（日 本電子製）で，検出器は波長分散型 $\mathrm{X}$ 線分光器を用いた。試 料は無蒸着状態とし, 分析径 $50 \mu \mathrm{m}$, 加速電圧 $7 \mathrm{kV}$ で分析し た.

\section{$2.10 \mathrm{X}$ 線光電子分光分析}

約 $0.2 \mu \mathrm{m}$ の厚さの薄膜をシリコンウエハー上に膜付けした 後, X 線光電子分光分析 (XPS) を行った，測定に用いた装 置は PHI 5600 (Perkin Elmer 製) で，励起源は $\mathrm{Al} \mathrm{K} \alpha$ 線 $(1486.6 \mathrm{eV})$ ，分析径は約 $800 \mu \mathrm{m}$ である.アルゴンによるス パッター処理を行う前と $1 \mathrm{~min}$ のスパッター処理を行った後 の試料についてそれぞれ表面分析を行った.

\subsection{1 電子スピン共鳴スペクトル}

電子スピン共鳴スペクトル (ESR) 測定用の基板としては $3 \times 40 \times 0.5 \mathrm{~mm}$ の合成石英を用いた．また， ESR 測定用サン プルチューブは密栓ができるもので, サンプルチューブをプラ ズマ反応器内部の極力プラズマの影響を受けにくい所に設置 し, 同時に基板を下部電極上に設置した. 排気後, 出発物質で あるイソプロパノールを導入し, 所定の条件で成膜を行った 後, 出発物質の導入を止め, 十分に真空引きを行った，その 後, アルゴンガスをリークした後, 反応器内のアルゴンガス雾 囲気下において, 成膜した基板をサンプルチューブ内に移した 後密栓し, 反応器から取り出し直ちに ESR スペクトルの測定 を行った. 成膜終了後, ESR スペクトルの測定むでおよそ 7〜10 min を要した.

用いた装置は日本電子製の JES-RE1X である.

ESR スペクトルの測定は X-band, $100 \mathrm{kHz}$ 変調, キャビ ティーに $25^{\circ} \mathrm{C}$ 恒温水を循環させながら行った. $g$ 值, 半值幅 $\left(\Delta H_{\mathrm{pp}}\right)$ 及び強度は $\mathrm{Mn}^{2+}$ 及び 4-hydroxy-2,2,6,6-tetramethyl piperidine-1-oxyl を標準物質として用いて決定した.

ESR スペクトルの測定には，高周波の出力が $100 \mathrm{~W}$ の場合 は 6 パルス（成膜時間 $30 \mathrm{~s}$ ), $200 \mathrm{~W}$ の場合は 3 パルス（成膜 時間15s）それぞれ成膜した薄膜を用いた。

\section{3. 結果と考察}

\section{1 成膜速度}

既報においても報告したように，通常のプラズマCVD 法に おいては，出発物質としてアルコール等の含酸素化合物を用い ると，その他の成膜パラメーターを同一にして比較した場合， 自己バイアス法と比べて $2 \%$ 程度と堆積速度は極めて小さく, しかもわずかにパウダー状の生成物が基板状に堆積し, 薄膜の 形成は起こらないという現象を観察している ${ }^{15)}$. 自己バイア ス法はシース領域におけるイオン衝撃を有効に活用する成膜手 法であるため，このような薄膜を形成しにくい物質であって も，成膜機構そのものがプラズマ中での反応とは異なることか ら, 薄膜形成能力が極めて高く, しかも薄膜の成膜速度も速 $(21)$.

図 2 に膜厚に関する成膜速度について示した，成膜速度は高 周波の出力が高くなるにつれて，大きくなる．また，高周波の 出力が同一の場合, 成膜温度の上昇につれて減少するが，これ は既報16)においても見てきたように基板表面における吸着確 率が温度の上昇につれて減少するためと推定される. 一方, こ の成膜速度をイソブタンを出発物質とするダイヤモンド状炭素 薄膜の形成 ${ }^{16)}$ と比較するとその成膜速度はおよそ $50 \%$ 程度と 低かった．これは出発物質中に含まれる酸素が薄膜からの脱離 反応を活発にし，アブレーションを促進させたことによるもの 


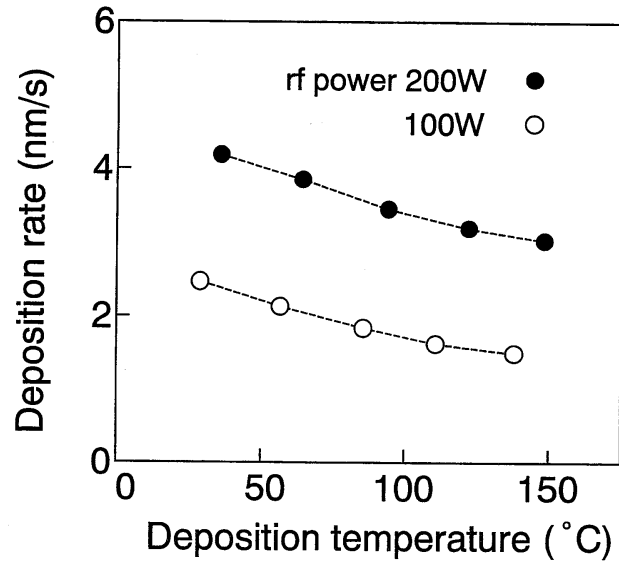

Fig. 2. Deposition rate versus deposition temperature for the film deposited at $100 \mathrm{~W}$ and $200 \mathrm{~W}$ r.f. powers.

である．むた，質量に関する成膜速度についても測定したが， 傾向は膜厚に関する成膜速度の場合とほぼ同様であった。

\section{2 自己バイアス電圧}

自己バイアス電圧は図 3 に示すように，印加した高周波出力 に大きく依存する，また，各高周波出力において，温度の上昇 につれて, 自己バイアス電圧がわずかに変動する傾向が観察さ れた。これはダイヤモンド状炭素薄膜において観察された結 果16) と同様な傾向であった．この現象は反応器内の下部電極 と支持体との間に絶縁のために用いられている石英板の温度特 性の変化等によるものと思われるが詳細は不明である.

\section{3 薄膜密度}

膜厚と質量に関する成膜速度から薄膜密度を算出し図 4 に示 した. 薄膜密度は高周波の出力が $100 \mathrm{~W}$ で成膜温度が低い場 合を除くと $1.8 \times 10^{3} \mathrm{~kg} / \mathrm{m}^{3}$ 程度であった. また成膜温度によ る密度の変化をみると, 高周波の出力が増加するとわずかに上 昇し，また，高周波出力が同一の場合，成膜温度が上昇する と，やはりわずかではあるが増加傾向を示すものの，イソブタ ンを出発物質としたダイヤモンド状炭素薄膜の形成の場合にみ られたほどの高周波出力依存性や成膜温度依存性 ${ }^{16)}$ は観察で きなかった．これは成膜表面からの酸素の脱離が薄膜構造を䇣 密化する方向にはたらき, 薄膜の高密度化がより進行したため と考えることができる。

\section{4 薄膜硬度}

図 5 にヌープ硬度を示した.これによれば，各出力において 成膜温度の上昇によって硬度が増加することが示されている. 最終的には $20 \mathrm{GPa}$ を超えるような極めて硬質な酸素含有炭素 薄膜が得られることが分かったが，この結果をイソブタンを出 発物質としたダイヤモンド状炭素薄膜の形成の際に得られた硬 度 ${ }^{17)}$ と比較すると, 大きな差違は観察されなかった. 硬度は, 薄膜内のネットワーク構造の緊密性と密接な関連があり, 前述 の密度の項と併せて考えると, 酸素含有炭素薄膜の場合は, 低 い成膜速度と引き替えに高密度, 高硬度という特性が得られる ことを示唆している.

\section{5 内部応力}

図 6 に薄膜の内部応力について, また図 7 に応力の測定温度 を $200^{\circ} \mathrm{C}$ ま゙変化させたときの内部応力の測定温度依存性をそ れぞれ示した。

既に報告したように16)薄膜の内部応力は薄膜自体が持つ真 性応力と, 基板と薄膜との熱膨張係数の差から生じる熱応力の 和として現れるが, 図 7 に示すように, 測定温度を変化させ

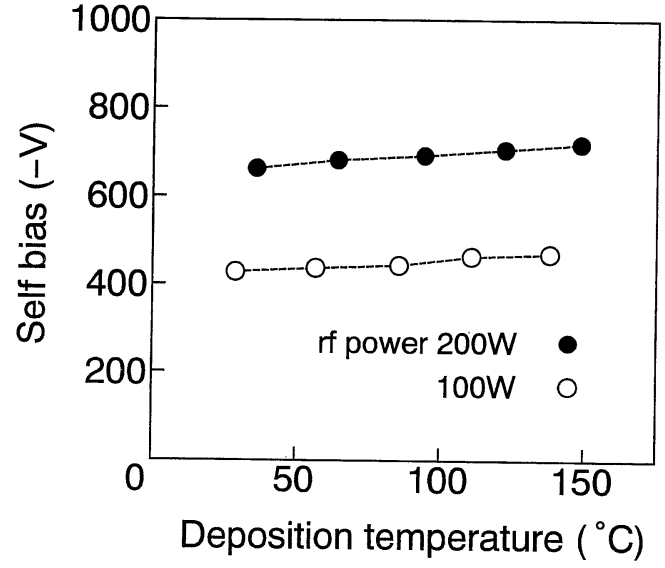

Fig. 3. Self-bias voltage generated in the film depositions at 100 $\mathrm{W}$ and $200 \mathrm{~W}$ r.f. powers.

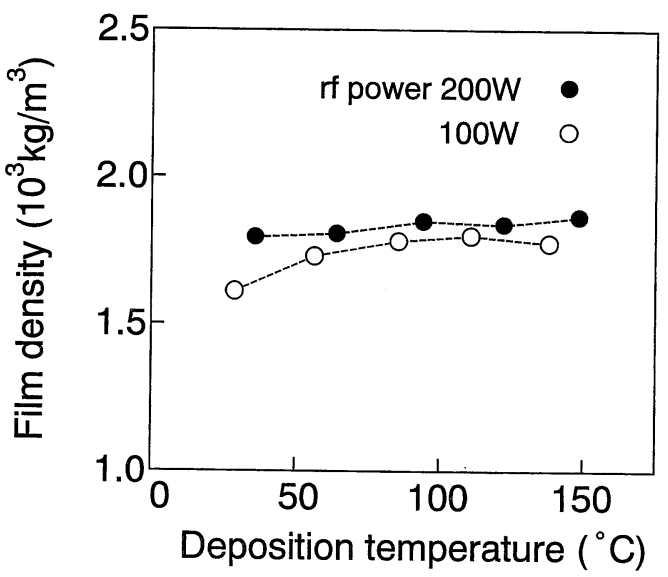

Fig. 4. Film density versus deposition temperature for the film deposited at $100 \mathrm{~W}$ and $200 \mathrm{~W}$ r.f. powers.

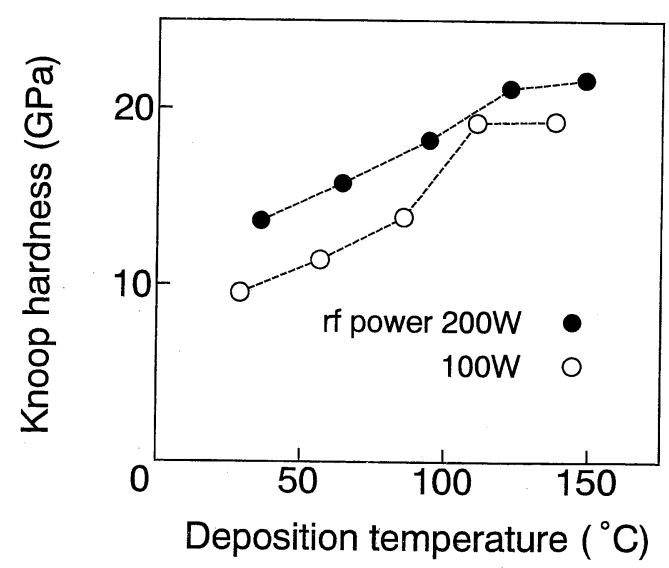

Fig. 5. Knoop hardness versus deposition temperature for the film deposited at $100 \mathrm{~W}$ and $200 \mathrm{~W}$ r.f. powers.

ても内部応力はほとんど変化しないことから, この場合, 熱応 力は無視し得るものと思われる.このことから，図 6 に示し た内部応力は薄膜自体が有する真性応力そのものと考えること ができる。

また, 得られた薄膜の真性応力はいずれも圧縮応力であった が, 高周波出力が高いと応力は増加し, 成膜温度についても, 


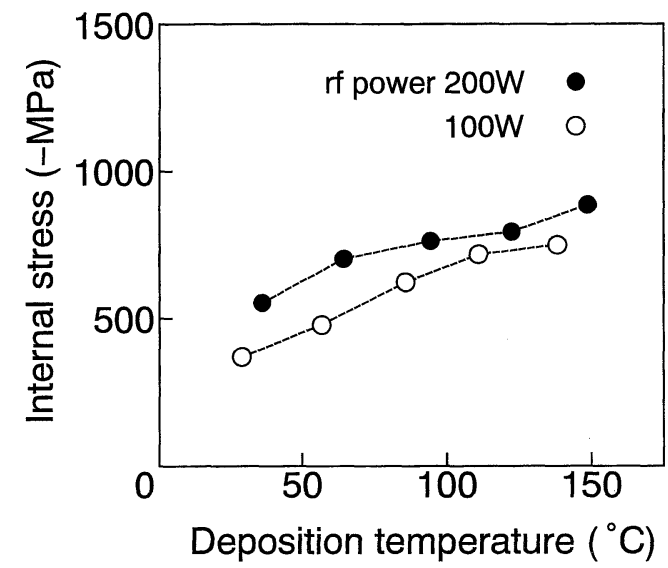

Fig. 6. Internal stress versus deposition temperature for the film deposited at $100 \mathrm{~W}$ and $200 \mathrm{~W}$ r.f. powers.

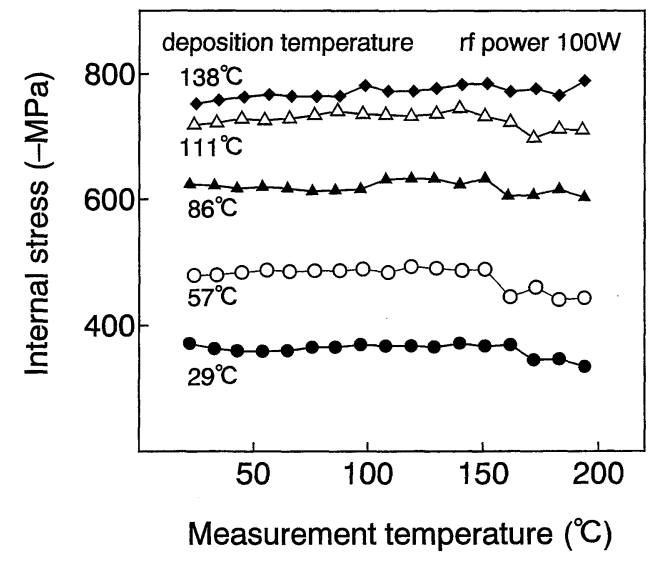

Fig. 7. Internal stress versus stress measurement temperature for the film deposited at $100 \mathrm{~W}$ r.f. power.

同様に高い方が応力が高くなる結果が得られた．この変化の傾 向は薄膜が十分高密度化している場合，イオン衝撃による成膜 表面への正イオンのくさび的な打ち込み効果が主として働くた めであり，この様子はイソブタンを出発物質としダイヤモンド 状炭素薄膜を形成した場合16) と同様であったが，真性応力の 值そのものはダイヤモンド状炭素薄膜に比べてやや低い結果と なった.

\section{6 マイクロラフネス}

成膜温度によって, 薄膜の表面形状がどう変化するかを, 原 子間力顕微鏡によって調べた，その結果，図８に示すように， 成膜温度の上昇による表面形状の平滑化は明確には確認でき ず，成膜温度による影響を受けにくいことが分かった。

粗さのパラメーターとして平均粗さ $\left(R_{\mathrm{a}}\right)$ を用い, 表面形 状を定量化して成膜温度との関係を示したのが図 9 である. イ ソブタンを出発物質としダイヤモンド状炭素薄膜を形成した場 合は成膜温度依存性が明らかで, 温度の上昇により表面形状は 平坦化する17). しかし出発物質に酸素が含有されていると, 酸素の脱離等に伴って表面反応が活発化することにより，吸着 種の移動性やイオン衝撃によって発生したフラグメントの自由 度が成膜温度が低くても比較的活性な状態にあると推定される ため, 明確な成膜温度依存性が観察できなかったものと思われ る.

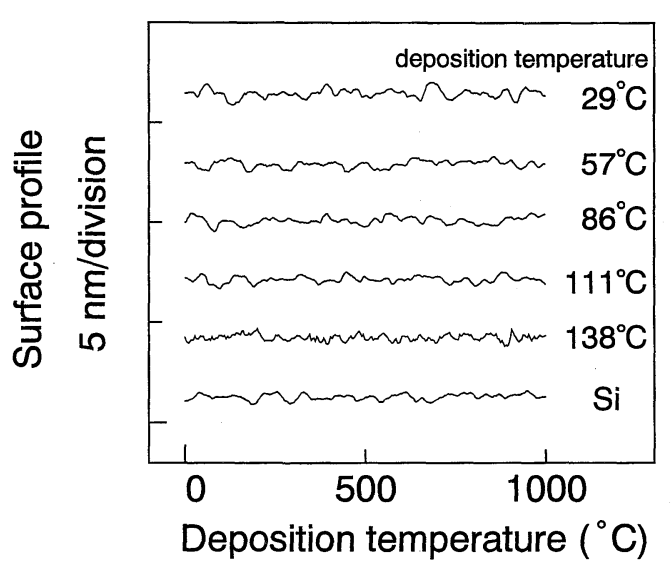

Fig. 8. Surface profile of the film deposited at $100 \mathrm{~W}$ r.f. power and various deposition temperatures.

$\mathrm{Si}$ : surface profile of the Si substrate.

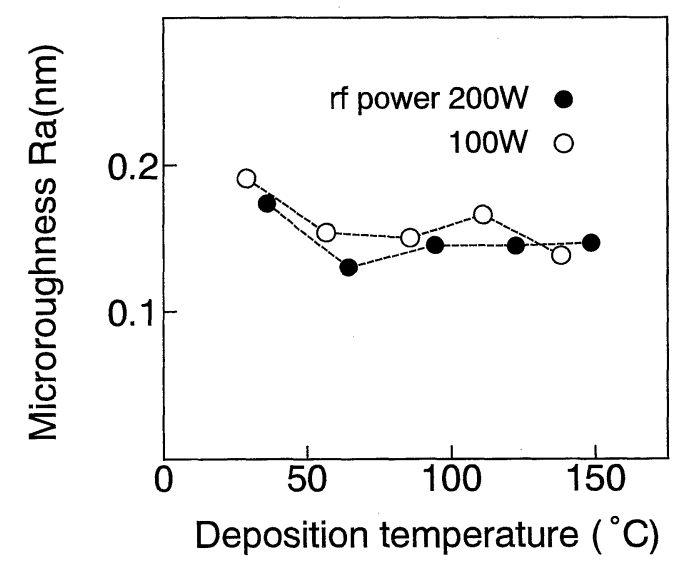

Fig. 9. Microroughness versus deposition temperature for the film deposited at $100 \mathrm{~W}$ and $200 \mathrm{~W}$ r.f. powers.

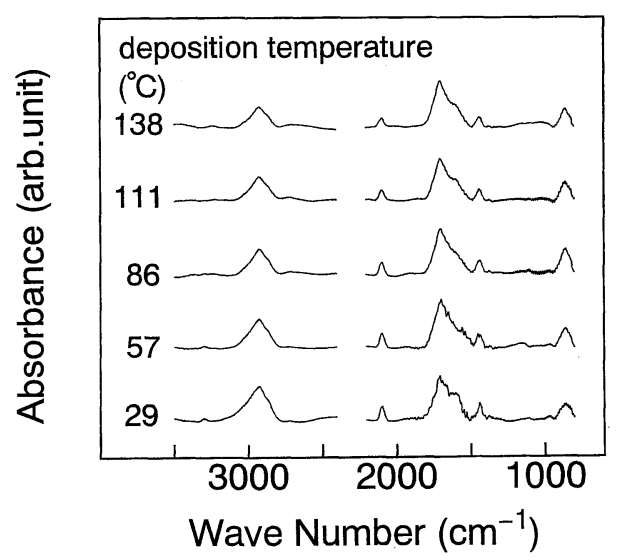

Fig. 10. IR spectra of the film deposited at $100 \mathrm{~W}$ r.f. power and various deposition temperatures.

\section{7 赤外吸収スペクトル分析}

図10に高周波出力を $100 \mathrm{~W}$ としたときの各成膜温度におけ る赤外吸収スペクトルを示した. 得られたピークは $2930 \mathrm{~cm}^{-1}$ 付近 (C-H 伸縮振動), $1440 \mathrm{~cm}^{-1}$ 付近 ( $-\mathrm{CH}_{2}$-変角振動), $1610 \mathrm{~cm}^{-1}$ 付近と $860 \mathrm{~cm}^{-1}$ 付近がベンゼン骨格に由来する ピークと推定され，これらの波形はイソブタンを出発物質とし 
たダイヤモンド状炭素薄膜の赤外吸収スペクトル17) と類似し ていた. 一方, $1710 \mathrm{~cm}^{-1}$ 付近と $2100 \mathrm{~cm}^{-1}$ 付近のピークは それぞれ $\mathrm{C}=\mathrm{O}$ 伸縮振動, $\mathrm{C}=\mathrm{C}=\mathrm{O}$ 逆対称伸縮振動に帰属さ れるものと考えられ，これらが薄膜中に酸素が含有されている ことにより観察された新たなピークである.

ここで観察された $\mathrm{C}=\mathrm{C}=\mathrm{O}$ 構造は, 酸素が $\mathrm{CO}$ 等の形で薄 膜中から脱離するときの前駆体構造と推定されるが，このよう な前駆体構造を薄膜中に確認した研究事例は他にないものと思 われる. 薄膜形成と形成された薄膜からの脱離反応が競争的に 起きている状況の中で, 本研究において用いた成膜法は薄膜形 成能力が他の CVD 法と比較してかなり高いことから，このよ うな脱離しようとする前駆体構造をも薄膜中に捉えているもの と考察される.

また，図10からも明らかなように，成膜温度の上昇による 赤外吸収スペクトルの大きな変化は観察されず, 成膜温度が低 くても酸素の存在によって脱酸素や脱水素反応がかなり進行し て，比較的均質な膜質を形成することを示している. しかしな がら, $2930 \mathrm{~cm}^{-1}$ と, $2100 \mathrm{~cm}^{-1}$ 付近のピーク強度が成膜温 度の上昇につれてわずかに低下する傾向を示していることか ら, 成膜温度の上昇はわずかではあるが脱酸素と脱水素, それ に伴う脱炭素反応を進行させるものと思われる.これらの結果 は, 上述した薄膜密度等において得られた結果と良く対応して おり, 比較的低い成膜温度でも薄膜構造の緊密化が進行するこ とを説明付けるものと考えられる.

また，高周波の出力が $200 \mathrm{~W}$ の場合の赤外吸収スペクトル も100 W の場合とほぼ同様な傾向を示した.

\section{8 ラマンスペクトル分析}

図11に高周波出力を $100 \mathrm{~W}$ としたときの各成膜温度におけ るラマンスペクトルを示した. 得られたスペクトルはいずれも $1530 \mathrm{~cm}^{-1}$ 付近にピークを持ち, $1350 \mathrm{~cm}^{-1}$ 付近にブロード な肩を持つスペクトルであった．これらはダイヤモンド状炭素 薄膜を形成した場合に観察された波形17) と極めて類似してい る.ダイヤモンド状炭素薄膜の場合, それぞれのピークは $\mathrm{G}$ ピーク（1530 $\mathrm{cm}^{-1}$ 付近）及び D ピーク（1350 cm-1 付近） と呼ぶことが多く, いずれも薄膜中のグラファイト状構造に起 因するものとの考察がなされており22) 25), 本薄膜中にも炭素 鎖による 3 次元的なネットワーク構造の中にグラファイト状 のカーボンクラスター構造が存在しているものと考えられる. ここではそれぞれのピークをピーク I $\left(1530 \mathrm{~cm}^{-1}\right.$ 付近 $)$ 及び ピーク II $\left(1350 \mathrm{~cm}^{-1}\right.$ 付近) として波形分離を行い, 成膜温度

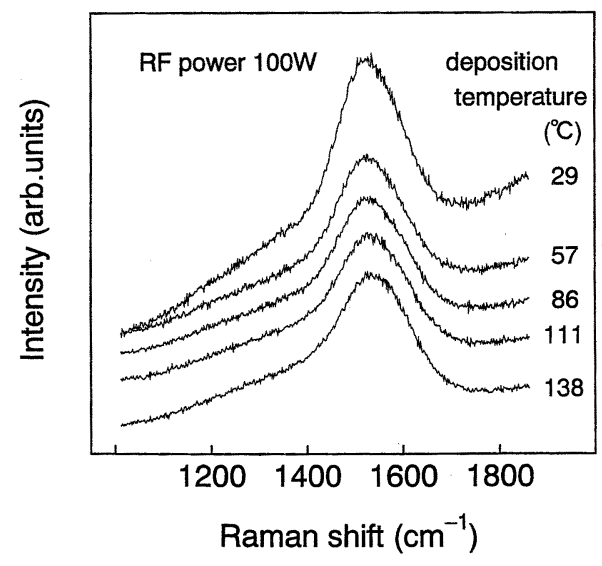

Fig. 11. Raman spectra of the films deposited at $100 \mathrm{~W}$ r.f. power and various deposition temperatures.

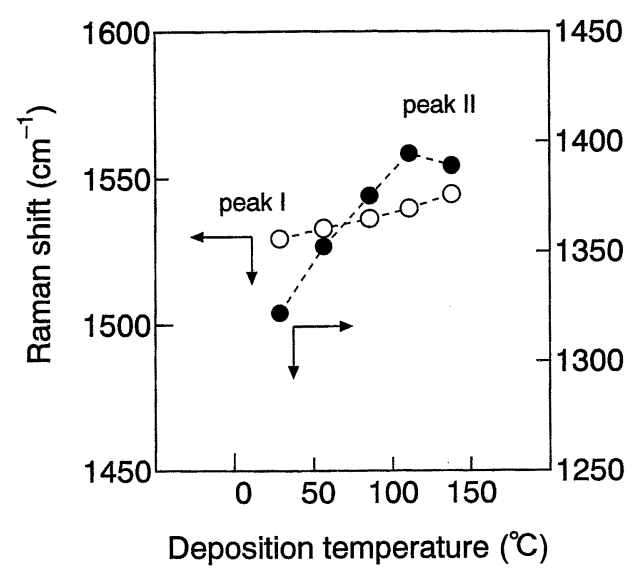

Fig. 12. Raman shift of peak I and peak II versus deposition temperature for the films deposited at $100 \mathrm{~W}$ r.f. power.

に対してそれぞれのピーク位置を示すと図12のようになり，い ずれのピーク位置とも成膜温度の上昇につれて, ピーク位置が 高波数側にシフトしていく様子が示されている．これは, 薄膜 の内部応力の変化等と良く対応するもので, 薄膜構造がより緊 密になり内部応力が増加するにつれてピーク位置が高波数側に シフトしたものと考えられる.

\section{9 組成分析}

EPMA の分析結果から薄膜中の $\mathrm{O} / \mathrm{C}$ 比を求め, 図13に示し た. EPMAの場合, 分析径や加速電圧, 薄膜の密度等により 分析領域が決められるが, 最表面だけでなく薄膜内部の組成情 報についても得られる利点がある. 図13の結果は薄膜の組成 としては炭素原子がかなり豊富に存在することを示しているも のの, 酸素原子も薄膜中に少量ではあるが取り込まれており, O/C 比で0.04程度であることを示している. しかもその元素 比は高周波の出力や成膜温度にほとんど依存せず，ほほ一定で あることから, 成膜温度や高周波の出力が低くても薄膜中から の脱酸素反応は極めて活発で, 薄膜の均質化に貢献しているこ とを示しており, 薄膜密度の項で得られた結果と良く一致す る.

一方, XPS 分析からも $\mathrm{O} / \mathrm{C}$ 比を求め, 図14に示した. この 結果を先の EPMA の結果と比較しながらみていくと, 明らか に $\mathrm{Ar}$ スパッター処理前の O/C 比の值はXPS の結果の方が大 きい值となっている. しかも高周波の出力が低いほど $\mathrm{O} / \mathrm{C}$ 比

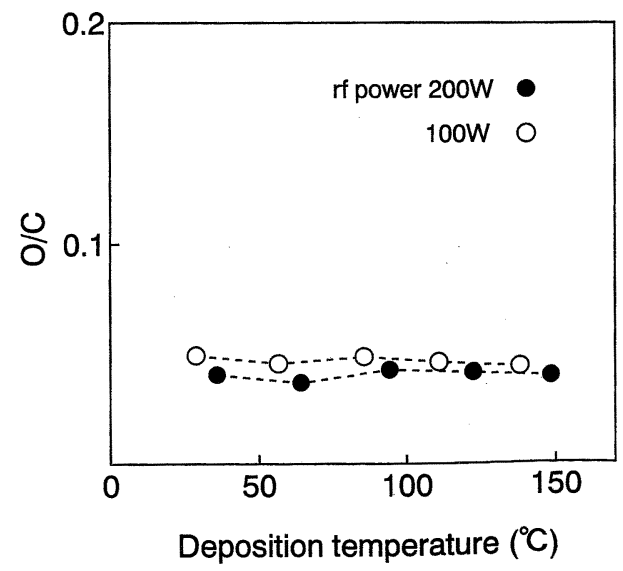

Fig. 13. $\mathrm{O} / \mathrm{C}$ ratio by electron probe microanalysis for the films deposited at $100 \mathrm{~W}$ and $200 \mathrm{~W}$ r.f. powers. 


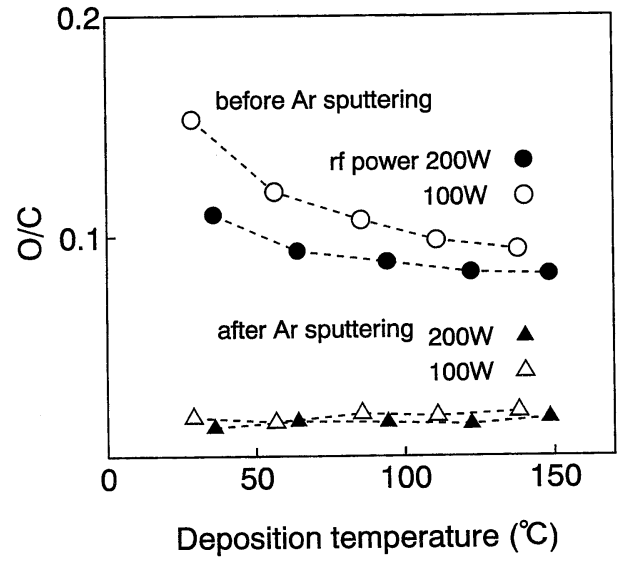

Fig. 14. O/C ratio by $\mathrm{X}$-ray photoelectron spectroscopy for the films deposited at $100 \mathrm{~W}$ and $200 \mathrm{~W}$ r.f. powers.

が大きく，更に成膜温度が低いほど $\mathrm{O} / \mathrm{C}$ 比が大きくなってお り, 高周波出力依存性之成膜温度依存性が観察され, EPMA の分析結果とは大きく異なっている. XPS の場合, EPMA と は異なり, 最表面の組成に関する情報が得られるので, 得られ た結果は抢そらく最表面に形成された酸化皮膜の組成であり, すなわちこの結果は薄膜自体の最表面における空気中の酸素之 の反応性を現しているものと考えられる.この観点から考察す ると, 成膜条件として高周波の出力が高いほど, また, 成膜温 度が高いほど得られた酸素含有炭素薄膜の耐酸化性は優れてお り,このことは上述した薄膜の緊密性等と関連づけて考えるこ とができる.

次に, $\mathrm{Ar}$ スパッター処理後のXPSの結果を見ていくと, O/C 比はいずれも0.015 0.02程度であり，これは EPMA で 得られた結果よりも更に低い值ではあったが, やはり薄膜中に 酸素が存在していることを示している. その存在傾向は EP MA で得られた結果とほほ同様であり, 高周波の出力や成膜 温度にほとんど依存しない。しかしXPS の場合 EPMA の結 果と比べて, O/C 比自体が小さい值となったのは, 恐らく $\mathrm{Ar}$ スパッター処理によって選択的に酸素がエッチングされたこと によるものと推定される.

これらの結果は, 薄膜中には酸素が存在せず, ダイヤモンド 状炭素薄膜を形成したとするKomath ら ${ }^{13)}$ の報告とは異なり, 明らかに膜中に酸素が存在することから, 本手法においては自 己バイアス法による成膜能力の高さがこのような結果をもたら したものと考えられる(15),21). 更に, 薄膜中における酸素の存 在形態は先に示した赤外スペクトルの結果等と併せて考えると $\mathrm{C}=\mathrm{O}$ 及び脱酸素反応の前駆体形として $\mathrm{C}=\mathrm{C}=\mathrm{O}$ 等の形で炭 素鎖による三次元的なネットワーク構造の中に取り込まれてい ると考えるのが妥当である.

\subsection{0 電子スピン共鳴スペクトル分析}

高周波の出力が $100 \mathrm{~W}, 200 \mathrm{~W}$ いずれにおいても，各成膜温 度においてブロードなピークが $g$ 值2.0028 2.0029に観察さ れた。この $g$ 值は既報 ${ }^{19)}$ において報告したダイヤモンド状炭 素薄膜の $g$ 值2.0027 とほぼ同じであり, 得られたスペクトル は炭素ラジカルに起因するものと考えられる. 図15に高周波出 力を $200 \mathrm{~W}$ としたときの ESR スペクトルを示したが, 既報に おいても報告した ${ }^{19)}$ のと同様に $E^{\prime}$ センターと呼ばれる基板と して用いた石英基板表面に発生したケイ素ラジカルに起因する シグナルを検出した. しかしこの $E^{\prime}$ センターはピークとして は小さく微量と考えられることから特に炭素ラジカルとの分離

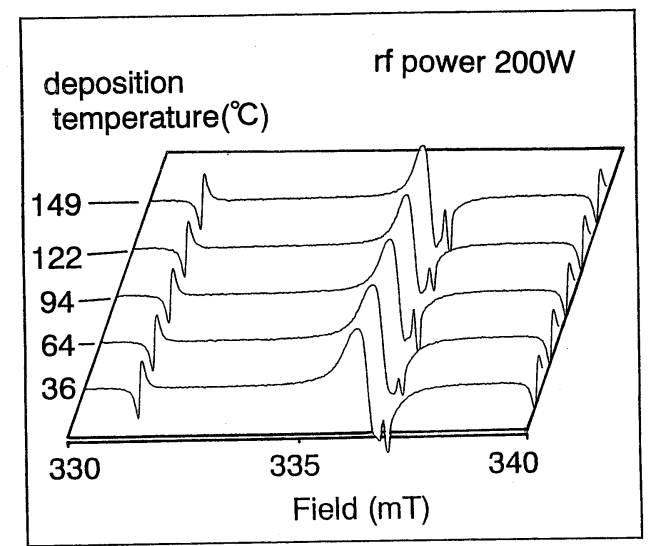

Fig. 15. ESR spectra of the films deposited at $200 \mathrm{~W}$ r.f. power and various deposition temperatures.

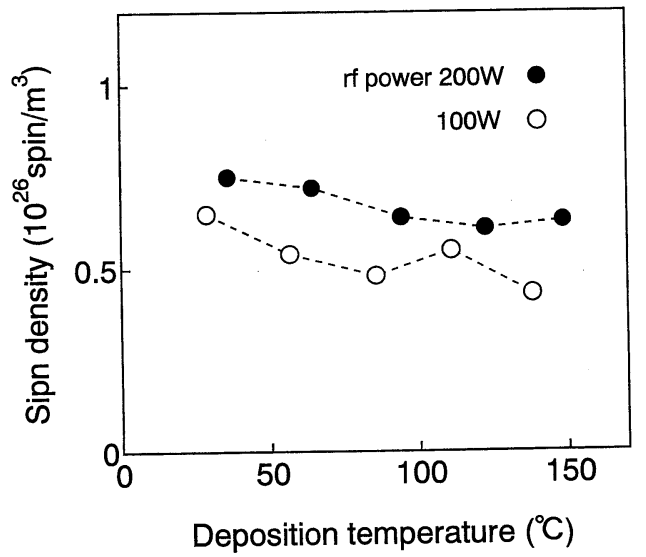

Fig. 16. Spin density versus deposition temperature for the films deposited at $100 \mathrm{~W}$ and $200 \mathrm{~W}$ r.f. powers.

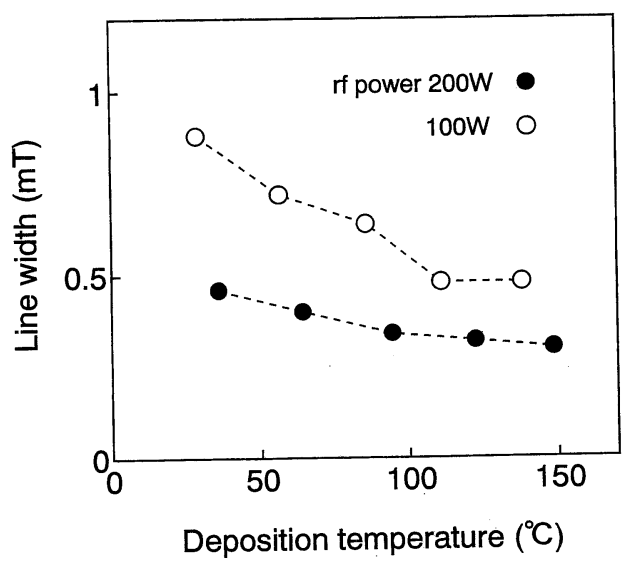

Fig. 17. Line width of ESR spectra versus deposition temperature for the films deposited at $100 \mathrm{~W}$ and $200 \mathrm{~W}$ r.f. powers.

操作は行わなかった．また，パーオキシドラジカルの生成も当 然予想されるが, このシグナルは極めてブロードであり, 例え 生成していたとしても今回の測定条件下では検出することはで きない.しかし $E^{\prime}$ センターを検出したことから，基板表面に ケイ素ラジカルが発生していることは確かなので，このラジカ ルと炭素ラジカルが反応して基板表面において $\mathrm{Si}-\mathrm{C}$ 結合を形 
成している可能性は十分考えられる.

図16にスピン濃度を，図17に線幅の変化を示した。スピン濃 度に関しては明確ではないものの成膜温度の上昇につれてやや 低下する傾向を示しており，ラジカル同土の反応が成膜温度の 上昇につれて活発になり薄膜の緊密化が進むことと対応してい るものと思われる。しかしながら，薄膜中に残存している炭素 ラジカル濃度はダイヤモンド状炭素薄膜において観察されたラ ジカル濃度 ${ }^{19)}$ と比較すると $20 \%$ 程度と低く，これが出発物質 及び薄膜中の酸素の影響であることは明らかではあるが，パー オキシドラジカルに関する情報が得られないので, 全ラジカル 濃度の挙動に関しては明確ではない。一方, 線幅については, 高周波出力が $100 \mathrm{~W}$ の場合，線幅は明確に低下する傾向を示 すものの，200 W の場合はその傾向は小さい，この詳細は明 らかではないが, $100 \mathrm{~W}$ の場合成膜温度の上昇につれて薄膜 の均質化が進むことで，炭素ラジカルに及ぼす各種の相互作用 が低下することによるものと考えられる．一方 $200 \mathrm{~W}$ の場合 は既に均質化がかなり進んだ状況と考えられるので, 線幅の変 化への影響は少なかったものと推定される．女た，薄膜中にグ ラファイト状のカーボンクラスター構造が存在するものと思わ れ, この存在量の変化等による線幅への影響も十分考えられ る.

\section{4. 結 論}

イソプロパノールを出発物質とし, 基板側に高周波を印加す る自己バイアス法を用いてパルス的な手法により成膜温度を制 御しつつ硬質炭素薄膜を作製した．このとき，少量ではあるが 薄膜中に酸素を含有した硬質炭素薄膜を形成することができ た.これは自己バイアス法の薄膜形成能力が極めて高いことに よるものと思われるが，薄膜形成時の脱酸素反応山極めて活発 に進行し，イソブタンを出発物質としてダイヤモンド状炭素薄 膜を形成する場合と比較すると成膜速度は50\%程度むで低下 した。一方，成膜温度の影響としてはダイヤモンド状炭素薄膜 を形成した場合とほぼ同様な傾向を示したが，脱酸素反応によ る薄膜の均質化がより進行し, 薄膜密度の増加や表面形状の平 坦化等が観察された。

薄膜の構造としては炭素鎖を主体とした三次元的なネット ワーク構造の中にカルボニル結合等により酸素が取り込まれ, 更に微量, 微小なグラファイト状のカーボンクラスター構造が ネットワーク構造の中に点在する系が最も妥当なものと推定さ れた. また,このとき, 酸素が脱離する時の前駆体構造と思わ れる $\mathrm{C}=\mathrm{C}=\mathrm{O}$ 結合が薄膜中に存在することが分かったが，こ れは本研究において用いた自己バイアス法の薄膜形成能力が高 いため,このような活性な構造をも薄膜中に取り込むものと考 えられた.
謝 辞 XPS スペクトルの測定及びその解析に打いて，適切 な御指導・御助言を頂きました工業技術院物質工学工業技術研究 所複合材料部・越崎直人氏並びに佐々木 毅氏に厚く御礼を申し 上げます。

\section{文 献}

1) I. Watanabe and K. Sugata, Jpn. J. Appl. Phys., 27 1397-400 (1988).

2) A. Inspektor, Y. Liou, T. McKenna and R. Messier, Surf. Coat. Technol., 39/40, 211-21 (1989).

3）瀬高信雄，表面技術協会講演大会講演要旨集， 84, 290-98 (1991).

4) R. A. Rudder, G. C. Hudson, J. B. Posthill, R. E. Thomas, R. C. Hendry, D. P. Malta and R. J. Markunas, Appl. Phys. Lett., 60, 329-31 (1992).

5) R. A. Rudder, G. C. Hudson, R. C. Hendry, R. E. Thomas, J. B. Posthill and R. J. Markunas, Surf. Coat. Thecnol., 54/55, 397-402 (1992).

6) M. Kadono, T. Inoue, A. Miyanaga and S. Yamazaki, Jpn. J. Appl. Phys., 32, 3231-36 (1993).

7) M. Ikeda, M. Hori, T. Goto, M. Inayoshi, K. Yamada, M. Hiramatsu and M. Nawata, Jpn. J. Appl. Phys., 34, 2484-88 (1995).

8）水野悦子, 山田浩二, 平松美根男, 縄田正人, 池田雅延, 堀 勝, 後藤俊夫, 電気学会プラズマ研究会資料, EP-95 (1995) pp. 27-34.

9) D. R. Gilbert and R. Singh, "Adv. Coat. Technol. Corros. Wear Resist. Coat.," Ed. by A. R. Srivatsa, C. R. Clayton and J. K. Hirvonen, The Minerals, Metals \& Materials Society (1995) pp. 273-79.

10) M. Ikeda, E. Mizuno, M. Hori, T. Goto, K. Yamada, M. Hiramatsu and M. Nawata, Jpn. J. Appl. Phys., 35, 4826-32 (1996).

11) T. Suzuki, T. Ishihara, T. Yamazaki and S. Wada, Jpn. J. Appl. Phys., 36, L504-06 (1997).

12) M. Ito, K. Murata, K. Aiso, M. Hori and T. Goto, Appl. Phys. Lett., 70, 2141-43 (1997).

13) M. Komath, M. Zambare, S. A. Gangal and S. K. Kulkarni, Diam. Relat. Mater., 4, 15-19 (1994).

14) P. L. Chen, M. Y. Tsai and G. R. Lai, Appl. Surf. Sci., 113/114, 238-43 (1997).

15) H. Yamada, T. Hiraide, O. Tsuji, T. Tatsuta, M. Sawai and P. Murawala, Proc. Jpn. Symp. Plasma Chem., 4 (1991) pp. 323-28.

16) H. Yamada, O. Tsuji and P. Wood, Thin Solid Films, 270 , 220-25 (1995).

17）山田秀雄, 辻 理, 炭素, 172, 105-10 (1996).

18) H. Yamada and O. Tsuji, J. Ceram. Soc. Japan, 105, 62-67 (1997) [in Japanese].

19) H. Yamada and O. Tsuji, J. Ceram. Soc. Japan, 106, 41-46 (1998) [in Japanese].

20）山田秀雄, 辻 理, 炭素, 181, 2-7 (1998).

21) 山田秀雄, 辻 理, 炭素, 182, 101-08 (1998)

22) M. Ramsteiner and J. Wagner, Appl. Phys. Lett., 51, 1355-57 (1987).

23）吉川正信，表面技術，42, 1217-22 (1991).

24）若木守明, 倉田保英, 奥山直樹, 安永 均, 大久保優生, プ レーティングとコーティング, 8, 307-11 (1988).

25) M. Yoshikawa, G. Katagiri, H. Ishida and A. Ishitani, Solid State Commun., 66, 1177-80 (1988). 